\title{
A VERNACULAR ARAMAIC STATEMENT FROM THE 10TH CENTURY HISTORY OF MOSUL BY AL-AZDI
}

\author{
AMIR HARRAK \\ UNIVERSITY OF TORONTO
}

\begin{abstract}
Vernacular Aramaic is usually a spoken language but to find a sentence uttered in this dialect as early as the $8^{\text {th }}$ century $C E$ is both rare and remarkable. The $10^{\text {th }}$ century al-Azdi, in bis History of Mosul, quoted this sentence said by a boatman and gave its translation in Arabic in the context of the invasion of Mesopotamia by the Abbasids. Even though the transmission of the Aramaic sentence partially distorted it and its translation is thus a bit problematic, there is no doubt about the linguistic origin and meaning of the sentence.
\end{abstract}

Yazīd ibn Muhammad ibn Zakariyyah al-Azdī is well known to modern historians of Middle Eastern studies through his major work entitled Tärikeh al-Mawsil (History of Mosul). ${ }^{1}$ We know next to nothing about his life, except that he was a member of the Azd tribe, Yemenite of origin, lived in Mosul

${ }^{1}$ The manuscript was edited by A. Habībah: Yazìd Ibn Muhammad ibn Zakariyyah al-Azudi: Tärikh al-Mawsil (Cairo, 1967). 
where he must have written his History, and died around AD 945 (AH 334). His History of Mosul is mostly local, focusing on the political, social and economic conditions of Mosul and the Jazirah (Upper Syria) during the early centuries of Arab rule.

Al-Azdi discusses the history of the $8^{\text {th }}$ and $9^{\text {th }}$ centuries in an annalistic manner, using the lunar calendar of Islam as a reckoning system. Some events are discussed briefly, some others at length, encompassing in some cases several folios. He concentrates on the early Abbasid period, the political aspect of which was his main focus. In this regard, he opposed the central authority of the Abbasid caliphs, as did some other mediaeval Arab (and Syriac) historians. ${ }^{2}$ His history has survived in a single manuscript now housed in the Chester Beatty Library in Dublin under the siglum Ms. Ar. 3030, dated to AH 654 (AD 1256).

Al-Azdi devotes several folios to discussing one of the most significant events in early Islamic history: the decisive battle between the Umayyad Caliph Marwān II and the Abbasid Abū al-'Abbās al-Saffāh. This battle in AD 750 led to the demise of the Umayyad Caliphate and the inauguration of the glorious Abbasid era. Several sources consulted by alAzdi contributed to the description of that military encounter, which took place near the Zāb river; as a consequence, his discussion offers a wealth of information of historical interest.

One of the accounts, which deals with the crossing of the Zāb by Marwān II, contains a non-Arabic statement made by a non-Arab and non-Muslim man. The account is found in folio $58 \mathrm{a}$ of the manuscript, published here in photograph by kind permission of the Board of Trustees of the Chester

2 See A. Harrak, The Chronicle of Zuqnin Parts III \& IV A.D. 488-775 (Toronto: Pontifical Institute of Mediaeval Studies, 1999), 17ff, 20. 
Beatty Library and the Gallery of Oriental Art, Dublin. ${ }^{3}$ At first glance, the statement lacking diacritics looks meaningless. But in light of the accompanying translation in Arabic, and keeping in mind that foreign statements suffer changes and even mutilation during transmission, an Aramaicist can feel confident that the statement under discussion is of Aramaic origin. At this point, let us present the statement in its original context provided by al-Azdī: ${ }^{4}$

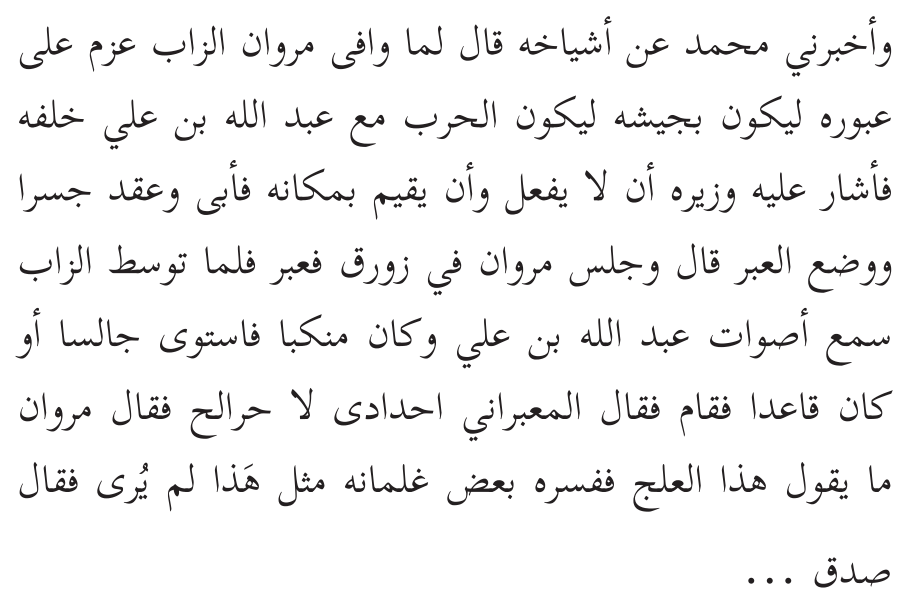

Relying on old men, Muhammad informed me, saying: When Marwān arrived at the Zāb, he decided to cross over it in order to be with his army, and in order that the fighting with ${ }^{~} A b d-A l l a h$ son of ${ }^{e}$ Ali be at his rear. Nonetheless, his vizier asked him not to do so, but rather to remain in his place; he declined to do so. He then put together a bridge, thereby making a crossing point. He [=the informer] said: Marwān sat in a boat and went to the other side. When he was still

${ }^{3}$ I would like to express my gratitude to Ms. Sinéad Ward for sending me the photograph and the permission to publish it, and to Dr. Elaine Wrights for providing me with the date of the manuscript, and taking the trouble of identifying the folio number not given in Habỉbah's edition.

4 Tärikeh al-Mawsil, p. 132. 
half way across the Zāb, he heard sounds of [the approach of] 'Abd-Allah son of ' $\mathrm{Ali}$, and therefore, he sat upright-if he had been bent over-or he stood up-if he had been sitting. Then the boatman said: 'ḅd'dy l' br'lh. Marwān said: What did this eilj say? Some of his servants interpreted it, [saying]: Anything like this was never seen. And he said: He is right!

Before we proceed to analyze the statement made by the boatman, let us reiterate that statements in unfamiliar or totally unknown languages are prone to suffer changes during transmission from one informant to another, and/or from one written source to another. The changes can be so drastic that they can totally obscure the original language in which the statements are made. The foreign statement in al-Azdī has been partially altered.

The first "word" of the statement is made of three elements: ' $h+d+$ ' $d y$. Arabic $h \vec{a}$ ' in the first element is often confused with $b \bar{a}$, since the only difference between the two is a mere dot; if this dot is placed over the common symbol, it becomes $b \vec{a}$ and if it is deleted the symbol becomes $b \vec{a}$ : $\tau / \tau$. The confusion between the two letters in Arabic manuscripts (and in modern handwriting or printing) is wellknown; therefore, it is safe to slightly modify the first part of the statement found in al-Azdī's History to read: (دادى) Arabic $\dot{\tau}^{\prime}$ is a close transcription of the Old Aramaic $y / k$ "as, like", also known in Imperial Aramaic, ${ }^{5}$ Mandaic, and mostly Syriac in the exact transcription [ax] (written plene <'ayk>). Several modern Aramaic dialects add a preformative mim to this [ax], resulting in the form [max]; but several other dialects preserve the Classical [ax] as in Alqosh, Upper and Lower Tiari, Ashitha, and so on. ${ }^{6}$

${ }^{5}$ J. Hoftijzer and K. Jongeling, Dictionary of the North-West Semitic Inscriptions (Part One, Leiden: E.J. Brill, 1995), p. 45.

6 A. J. Maclean, Dictionary of the Dialects of Vernacular Syriac (Oxford: The Clarendon Press, 1901), p. 10. 
The second element is the relative particle /d/ (the familiar dy or ay attested in every Aramaic dialect), which often follows the preposition 'yk forming the phrase ' $y$ k zy in Old Aramaic and [axd] "as" in Classical Syriac.

The third element is ادي ['dy]. This is none other than the demonstrative pronoun $3 \mathrm{fs}$ attested as hd' in Hatran, Jewish Aramaic, and Syriac. In Syriac it is spelled [haðe], but the [h] is usually lost in spoken Aramaic where it is pronounced [aðe]. Thus, the Arabic transcription reflects the same dialectal form in modern Aramaic still used in the region of Mosul. In fact, the phrase [exdaði] (sometimes [xdaði]) "like this" used in Alqosh ${ }^{7}$ sounds similar to the Aramaic phrase transcribed in al-Azdī's History.

The second "word" of the statement made by the boatman presents no difficulty whatsoever: Arabic $\vee[\bar{l}]$ is Aramaic [lā], used in connection with negative statements. Its role in the statement of the boatman is correct, as the Arabic translation of this statement given in al-Azdī also makes clear.

The final "word" of the Aramaic statement under discussion is composed of three elements, the verb حرا [hr'] and the preposition /1/ ligatured with a pronominal suffix: $ح$ [lh]. To be sure, this verbal form and its translation are not correctly given. The first element must disguise the Aramaic $\sqrt{h}$ zy " to see," where a dot over the Arabic letter $r a \bar{a}$ ' is missing, though it is needed to read the word حرا حرا a (the whole phrase would be حزالح). This form, because it is followed by the prepositional phrase, must be parsed as the passive participle [hze] and not as the $3 \mathrm{~ms}$ perfect [hza]. Such a structure is well known not only in vernacular Aramaic but also in Babylonian Aramaic and classical Syriac and as early as Imperial Aramaic. Nonetheless, pharyngeal [h] often shifts to velar $[\mathrm{x}]$ in vernacular Aramaic, and thus the form would be pronounced [xze]. If this were the case in $8^{\text {th }}$ century

7 This town inhabited by Christians speaking Neo-Aramaic is located some $45 \mathrm{~km}$ north of Mosul, and contains the tomb of the biblical Prophet Nahum. 
Mesopotamia, a dot over Arabic $h \bar{a}$ ' would have dropped as easily as did the dot of the letter $q \bar{a}$. There is no explanation why the statement has an /a/ vowel in حرstead of $y \vec{a}^{\prime}\left({ }^{*}\right.$ in to conform with the Aramaic passive [hze], but to a foreign ear the sound /a/ versus /e/ and vice-versa must not have made a great difference.

The Arabic translation of Aramaic $1, \mathrm{l}$, which includes a verb in the passive, seems to be an interpretation rather than a translation. In fact, the whole Arabic statement is

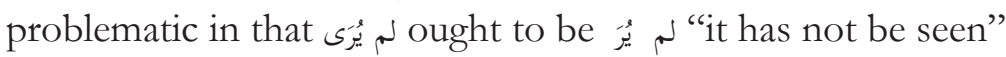

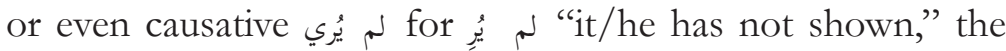
latter case being unlikely. Most probably the damma is an error

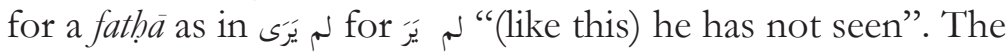
author or the copyist of the History of Mosul must have been confused by the translation of the statement since he missed

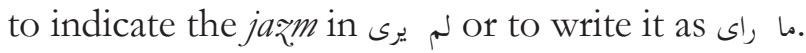

The real puzzle is the following $ح[1 \mathrm{~h}]$. One would expect here the Aramaic preposition /1/ followed by the pronominal suffix $3 \mathrm{~ms}$ [leh] "by him," in which case the Arabic transcription would be ليه (leh) or (li) rather than the actual $\checkmark$ (lah). In fact, if the Arabic translation is correct, the Arabic transcription of this pronoun can be justified through modern Aramaic. The [h] shifts to [h] in the Aramaic dialect of Qaraqosh, an important Christian town located near Mosul, ${ }^{8}$ which prides itself on the fact that it still speaks Aramaic as its first language. More importantly, this shift occurs specifically in the $3 \mathrm{~ms}$ pronominal suffix, as the following examples illustrate: [didaḥ]" for *[dileh] "his,

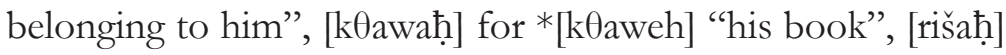

${ }^{8}$ Qaraqosh, located to the east of Mosul, still speaks Neo-Aramaic as is also the case of the nearby Christian towns, Barțellī and Karamlēs. Its dialect has never been the subject of an analytical study.

${ }^{9}$ In the case of [didah], the preposition /1/ before the $3 \mathrm{~ms}$ pronoun assimilated with the relative particle / $\mathrm{di}^{-} /$as is more common in Babylonian Aramaic. 
for [rišeh] "his head", and so on. حزالح häälạ could well transcribe Aramaic [hzalah] < hyzālah $>$ of Qaraqosh. In other words, if $[\mathrm{h}]$ shifts to [h] in the modern Aramaic dialect of Qaraqosh, this shift could well have occurred centuries earlier as shown in the History of al-Azdī.

If the Arabic translation of the vernacular Aramaic statement is يُر مَر and of the manuscript, the translation would literally reflect the Aramaic original [hza], as suggested by the analysis of the $3 \mathrm{~ms}$ Aramaic verb rendered by the same person, gender, and number in Arabic. Nonetheless, one would expect the Aramaic statement to be a direct speech, and its verb $1 \mathrm{msc}$ rather than $3 \mathrm{~ms}$. The boatman must have been frightened by the scene of the pursuing Abbasid armies, since it was near the Zāb River that the decisive battle between the Umayyads and the Abbasids took place. It seems reasonable therefore that the boatman would cry out: "I have never seen anything like this!" As an answer to the Caliph's inquiry about the boatman's reaction, the servants told the belligerent Caliph that he $(=$ the boatman) had never seen anything like this before.

If this scenario is correct, an additional emendation in the Arabic transcription should be made: final $ح$ حزالح حزäalahb "he saw" should be changed into $y \bar{a}$, as in *<hzăli $>$ "I saw". Admittedly, it is not easy to justify this emendation epigraphically, though scribes can be careless in copying texts written in their own language, and even more careless in copying foreign names and terms. The midthirteenth-century scribe who copied the History of al-Azdi is a case in point, since the editor of the manuscript detected an unusual number of errors, especially in personal names, to which he called attention in footnotes. ${ }^{10}$ The form حزالي* corresponds to the more common vernacular Aramaic [hzeli], in which the pronominal suffix is the familiar yodh/yä.

The Aramaic origin of the statement made by the boatman is beyond doubt. In additional support of that

${ }^{10}$ Habībah, Tärikeh al-Mawsil, p. 8 and note 3. 
origin, one may add the non-Arab and non-Muslim identity of the speaker. Upon hearing the statement, Caliph Marwān asked about the speaker whom he designated ${ }^{\mathrm{i}}$ ij. This Arabic term refers to the wild ass known for its strength, as well as to powerful men among the Persian infidels, and by extension to any non-Muslim man. ${ }^{11}$ The boatman was one of these, and since he spoke Aramaic he could have been a Christian, Jew, or Mandean, since all of these non-Muslims spoke various dialects of Aramaic.

In conclusion, the recording of a vernacular Aramaic sentence once made during the middle of the $8^{\text {th }}$ century is truly remarkable. While Classical Aramaic, namely Syriac, is well attested down to the $19^{\text {th }}$ century of our era, vernacular Aramaic remained unrecorded, and left few witnesses in its long history. Al-Azdī's History of Mosul offers us a glimpse of an Aramaic dialect that was spoken in the early medieval period in the north of Iraq.

\section{BIBLIOGRAPHY}

Al-Bustānī, 'Abdullah, al-Bustān, vol. II (Beirut: al-Mațba ${ }^{e} a h$ al-Amirikāniyyah, 1930).

Habībah, A.: Yazid Ibn Mubammad ibn Zakariyyah al-Azdì: Tärikeh al-Mawșil (Cairo 1967).

Harrak, A., The Chronicle of Zuqnin Parts III \& IV A.D. 488-775 (Toronto: Pontifical Institute of Mediaeval Studies, 1999).

Hoftijzer J., and K. Jongeling, Dictionary of the North-West Semitic Inscriptions, Part One (Leiden: E.J. Brill, 1995).

11 eAbdullah Al-Bustānī, al-Bustān, vol. II (Beirut: al-Mațba âh alAmirikāniyyah, 1930), p.1637. 
Maclean, A. J., Dictionary of the Dialects of Vernacular Syriac (Oxford: The Clarendon Press, 1901).

\section{APPENDIX}

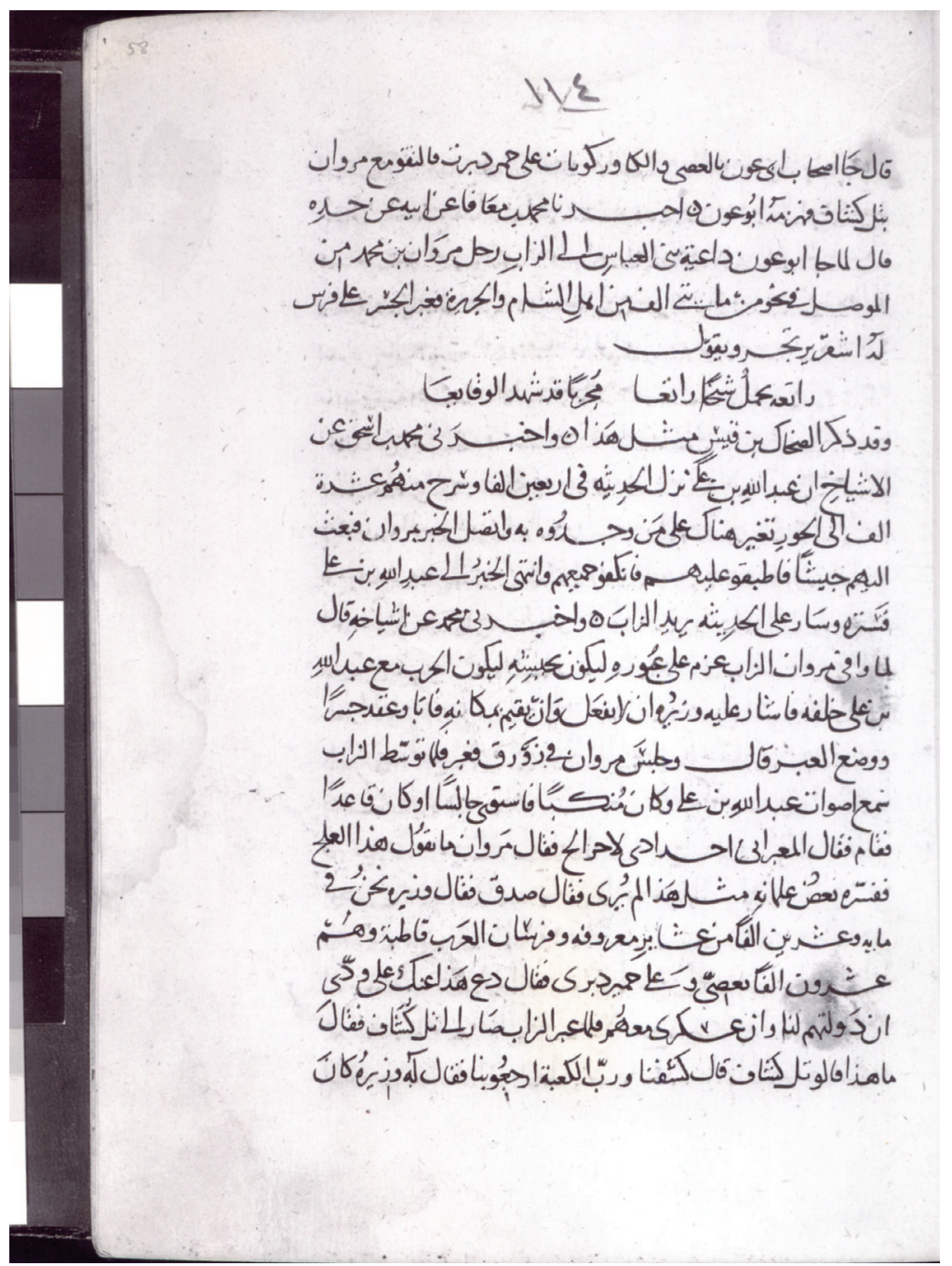

Image: folio 58a in Ms. Ar. 3030, Chester Beatty Library in Dublin 
